\title{
Impacts of limestone and nitrogen top dressing application on the potassium content in the soil profile and marandu-grass leaf concentration ${ }^{1}$
}

\author{
Geraldo Balieiro Neto², Ricardo Andrade Reis ${ }^{3}$, Ana Cláudia Ruggieri ${ }^{3}$
}

\footnotetext{
${ }^{1}$ Pesquisa financiada pela FAPESP.

${ }^{2}$ Agência Paulista de Tecnologia dos Agronegócios - APTA Centro Leste. Av Bandeirantes 2419, Ribeirão Preto, SP.

${ }^{3}$ Faculdade de Ciências Agrárias e Veterinárias da Universidade Estadual Paulista - FCAVIUNESP.
}

\begin{abstract}
The objective of this experiment was to evaluate the effects of nitrogen doses $(0,100,200,300$, and $400 \mathrm{~kg} \mathrm{ha}^{-1}$ year $^{-1}$ ), with or without dolomitic lime covering application, on the potassium (K) soil content at depths varying form 0 to 5,5 to 10 , and 10 to $20 \mathrm{~cm}$, and the potassium concentration in the plant. The experiment was carried out in a rhodic ferralsol with a slightly rolling relief, in a $5 \times 2$ factorial arrangement, in a complete randomized block design, with four replications. Nitrogenated fertilization caused a linear increase in the potassium concentration in the plant and also in the mineral content in the 0-5 cm soil layer. An effect of competitive inhibition occurred between the potassium and calcium absorption, and potassium and magnesium absorption. Although a significant fraction of potassium returned to the soil surface layer through the forage residue due to the increase in dry matter production caused by nitrogenated fertilization, the increase in the potassium concentration in the plant due to the doses of nitrogen demonstrated the importance of considering the potassium supply to the plant, when the forage mass is intensified through nitrogenated fertilization.
\end{abstract}

Key Words: mineral nutrition, soil fertility, urea, Urochloa

\section{Impactos da aplicação de calcário e nitrogênio em cobertura no teor de potássio no perfil do solo e na concentração foliar do capim-marandu}

\footnotetext{
RESUMO - Objetivou-se avaliar os efeitos de nitrogênio (0, 100, 200, 300 e $400 \mathrm{~kg} / \mathrm{ha}$.ano), com ou sem aplicação de calcário dolomítico em cobertura, sobre o teor de potássio (K) do solo nas profundidades de 0 a 5 ; 5 a 10 ; e 10 a $20 \mathrm{~cm}$ e a concentração de potássio na planta. O experimento foi realizado em Latossolo Vermelho distroférrico de relevo suavemente ondulado, disposto em esquema fatorial $5 \times 2$, em blocos casualizados, com quatro repetições. A adubação nitrogenada promoveu aumento linear na concentração de potássio na planta e no teor desse mineral na camada de 0 a 5 cm do solo. Ocorreu efeito de inibição competitiva entre a absorção de potássio e cálcio e entre potássio e magnésio. Embora uma fração significativa de potássio retorne à camada superficial do solo pelo resíduo de forragem, em decorrência da maior produção de massa, o aumento da concentração de potássio na planta nas mais altas doses de nitrogênio comprova a importância do suprimento de potássio para a planta, por intensificar a massa de forragem.
}

Palavras-chave: fertilidade do solo, nutrição mineral, uréia, Urochloa

\section{Introduction}

Cattle production on pastures in Brazil provides excellent market competitiveness, because it reduces production costs. The rational use of this resource is fundamental for increasing forage allowance and quality for ruminant nutrition.

Pasture degradation reduces forage productivity and quality and directly affects the nutritional condition of the herds and the economic performance of the activity. The area of degraded pastures, or those in the process of degradation, is thought to reach up to more than
$50 \%$ of cultivated pastures (Barcellos, 1996). The exhaustion of soil fertility and the improper fertilizer and corrective application are the main causes of pasture degradation.

Considering the condition of the majority of the soils in Brazil, measures to correct this acidity need to be adopted. However, in the situations in which the soil requires lime, and this correction has not been made prior to pasture formation, the mechanical operation to incorporate the lime may affect plant populations. On the other hand, when it is applied on the soil surface without incorporation, an interaction with the efficiency of using 
other fertilizers may occur. Thus, the recommendation on liming pastures requires better elucidation.

Marandu-grass is greatly used in Brazilian pastures, thus integrating the degradation scenario, due mainly to the cultivation of this forage grass in soil with fertility below the plant's nutritional needs. According to Alvim et al. (1990), marandu-grass is more responsive to nitrogenated fertilization compared to the gramineae from the Urochloa species.

Nitrogen deficiency has been indicated as the main cause of this degradation, and the efficiency of the nitrogen application may be influenced by the potassium level. In an experiment carried out in Colombia, with total withdrawal of the forage mass, the potassium extraction during the cuts reduced the response of the Urochloa decumbens to nitrogen doses in the second and third years of the experiment (CIAT, 1980). Presently, with the need to intensify forage production, the improvement and maintenance of soil fertility in pastures is a research target, especially because of questions related to the greater nutrient exportations in more intensive systems. The objective of the present study was to evaluate the effect of lime application associated with nitrogen on the potassium content in the soil profile and the leaf concentration of this mineral in marandu-grass plants.

\section{Material and Methods}

This experiment was carried out from March 2004 to April 2006 in a pasture established in rhodic ferralsol with slightly rolling relief (Embrapa, 1999), using Urochloa brizantha (Stapf) Webster cv. Marandu, at $21^{\circ} 08^{\prime}$ S latitude and longitude $47^{\circ} 59^{\prime}$ W longitude and $548 \mathrm{~m}$ altitude.
The predominant climate is classified as Aw (Köppen, 1948), characterized as humid tropical climate, with hot, rainy summer and dry winter. The average annual temperature varies from $27.3^{\circ} \mathrm{C}$ to $31.5^{\circ} \mathrm{C}$, and the average minimum temperature, from $11^{\circ} \mathrm{C}$ to $18^{\circ} \mathrm{C}$, with minimum values of $7^{\circ} \mathrm{C}$ in June, and $20^{\circ} \mathrm{C}$ in January, February, March, and October. In general, the dry season occurs from April to September and the rainy season from October to March. The average rainfall in the rainy season is $1,485 \mathrm{~mm}$, equivalent to $80.5 \%$ of the total, and $359 \mathrm{~mm}$ in the dry season, equivalent to $19.5 \%$ (Figure 1 ).

Pasture was sown in 1986 after corn cropping for two consecutive years. The pasture was established only on the residual fertilization of the corn crop. One year after introducing marandu grass, nitrogen ( $50 \mathrm{~kg} / \mathrm{ha}$ ) was applied and afterwards the area was maintained for 18 years without any fertilizer application. Twenty sub-samples were collected at $0-20 \mathrm{~cm}$ on the ground. In the soil analysis, the chemical composition was verified: $4 \mathrm{mg} / \mathrm{dm}^{3}$ P resin; $47 \mathrm{~g} / \mathrm{dm}^{3} \mathrm{MO} ; \mathrm{pH} 4.7 \mathrm{inCaCl}_{2} ; 1.8 \mathrm{mmol}_{\mathrm{c}} / \mathrm{dm}^{3} \mathrm{~K} ; 22 \mathrm{mmol}_{\mathrm{c}} / \mathrm{dm}^{3}$ of Ca; $11 \mathrm{mmol}_{\mathrm{c}} / \mathrm{dm}_{3}$ of $\mathrm{Mg} ; 58 \mathrm{mmol}_{\mathrm{c}} / \mathrm{dm}^{3}$ of $\mathrm{H}+\mathrm{Al}$, at CTC of $93 \mathrm{mmol}_{\mathrm{c}} / \mathrm{dm}^{3}$; and saturation per bases (V) equal to $38 \%$.

The pasture was stockpiled and an intermittent stocking grazing system was adopted with forage allowance at $8 \%$ body weight. Caracu breed cows, $500 \mathrm{~kg}$ average body weight (BW) were used.

A $2 \times 5$ factorial arrangement in a complete randomized block design was used, with four replications. The lime dose was calculated to reach saturation per bases by $50 \%$ in the 0-20 cm layer. Nitrogen doses were 0, 100, 200, 300, and $400 \mathrm{~kg} / \mathrm{ha}$.year, both in absence and in presence of broadcasting lime.

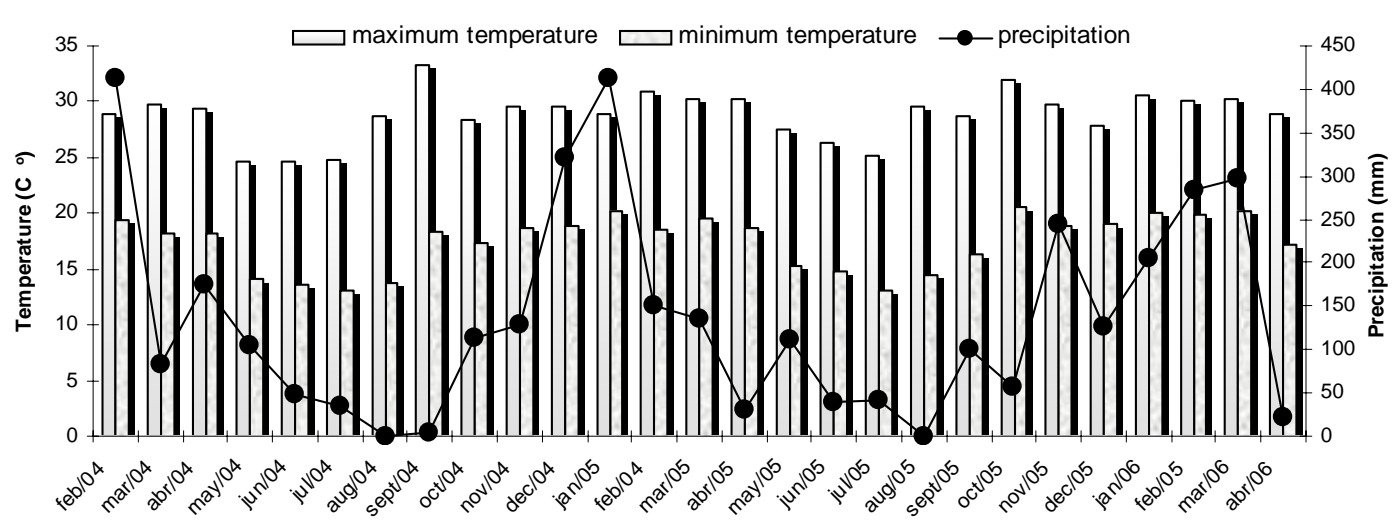

Figure 1 - Monthly rainfall and maximum/minimum temperatures in the Advanced Technololgical Research Center for Beef Cattle Agribusiness, Sertãozinho Animal Science Institute (Centro Avançado de Pesquisa Tecnológica do Agronegócio de Bovinos de Corte, Instituto de Zootecnia de Sertãozinho) São Paulo, from February 2004 to April 2006. 
The used area was $11,055 \mathrm{~m}^{2}$, in a paddock containing all the experimental plotss. The total area of the experiment was greater than the sum of the plot area, since the blocks were arranged on each level curve, thus the width of four level curves was added, plus a side area for food and watering troughs, and an entrance for machines. Ten portions plots were used in each block, in which the treatments were randomized. The size of the plot used for each treatment was $80 \mathrm{~m}^{2}$, measuring $8 \mathrm{~m}$ by $10 \mathrm{~m}$. There was a distance of $1 \mathrm{~m}$ between the plots that served as a wagon trail, and at the side of each plot there was a $1 \mathrm{~m}$-wide enclosure, totaling a useful area equal to $48 \mathrm{~m}^{2}$ for sample removal.

To avoid applying the fertilizers on top of the tussocks, forage was removed prior to their application. After the forage elimination, $1.1 \mathrm{t} / \mathrm{ha}$ dolomitic lime was distributed without incorporation in the treatments that would receive lime. The lime presented 101\% PRNT, 45.65\% CaO, and $8.40 \% \mathrm{MgO}$.

In 2004 and 2005, $N$ doses of 100, 200, 300, and $400 \mathrm{~kg} / \mathrm{ha}$ were applied. Urea $(45 \% \mathrm{~N})$ was used as a nitrogen source, divided in two equal doses in November and December, soon after the grazing in successive cycles. Sulfur and potassium were applied equally with the first application in all treatments. The phosphorus fertilization consisted of an application of 90 and $60 \mathrm{~kg} / \mathrm{ha} \mathrm{P}_{2} \mathrm{O}_{5}$ in the $1^{\text {st }}$ and $2^{\text {nd }}$ year, respectively, using simple superphosphate. The potassium fertilization consisted of an application of $40 \mathrm{~kg} / \mathrm{ha}$ of $\mathrm{K}_{2} \mathrm{O}$ using $\mathrm{KCl}$. In October 2004/2005, samples were taken from the soil at depths of $0-5,5-10$, and 10-20 cm (20 simple samples for each compound sample), which were analyzed according to Raij et al. (1987).

To evaluate the potassium concentration in the plant, the leaf blade was analyzed three times during the summer (December, January, February) and two times during the winter (June and August). The rest period was between 28 and 32 days from December to April, and between 48 and 60 days from June to August, due to environmental conditions, such as temperature, luminosity, humidity, and soil fertility, as well as the relative and absolute growth rate at the $28^{\text {th }}$ and $56^{\text {th }}$ days of marandu-grass growth, respectively (Santos Junior et al., 2004).

Twenty-eight tillers and two laminas of recently expanded leaf per tiller (56 laminas) were separated from each plot (Mattos \& Monteiro, 1998). After separating, the leaves were washed in tap water and afterwards in distilled, deionized water, plus neutral detergent EXTRAN (solution at $0.1 \%$ ), and rinsed in distilled water without detergent (Santos Junior et al., 2004). After washing, they were dried with absorbent paper towels, then packed into perforated paper bags and put to dry in a forced air oven at $65^{\circ} \mathrm{C}$, until constant mass. Later, the samples were analyzed for chemical determination of Ca, Mg, and K (Sarruge \& Haag, 1974). To evaluate the dry matter production per hectare, a $1 \mathrm{~m}^{2}$ square, was thrown four times randomly on the useful area in each plot. The forage inside the square was removed at close-cut from the soil and weighed. One sample was dried in oven at $65^{\circ} \mathrm{C}$ during 72 hours to obtain the dry matter content. Subsequently, the dry matter production per hectare was calculated.

The effects of lime, nitrogen, season, and all the possible interactions were included in the model. In the case of significant effect for liming, season, and nitrogen $\times$ liming $\times$ season interactions, the Tukey test was applied at the $5 \%$ level of significance. Next, an analysis of the polinomial linear regression was made with a regressive variable for the first and second grade components. The statistical analyses were carried out using the Statistical Analysis System (SAS, 2003). Potassium in the leaf blade was analyzed by repeated measures in time using the PROC MIXED. For the study of correlation between the nutrients, the PROC CORR was used, and for analyses of regression, the PROC REG.

\section{Results and Discussion}

No effect of lime or lime $\times$ nitrogen interaction was observed on the potassium content in the soil (Table 1). Nitrogen had a positive linear effect on the potassium content in the 0-5 cm layer (Figure 2), but no effect on the others. The effect of nitrogen on the potassium content in the soil may be explained by the increase in the forage mass with the nitrogen doses (Figure 2). The no effect of nitrogen on the soil potassium content in the layers below $5 \mathrm{~cm}$ indicated that the nutrient cycling may have occurred only in the soil surface (Table 1), since, the forage residue decomposition probably occurred in the soil surface as well.

The potassium absorbed by the plants is not incorporated in the organic fraction, and remains in the plant as an ion (Mengel \& Kirkby, 2001). Furthermore, the potassium incorporated in the organic matter may be liberated through the decomposition of this fraction by microorganisms, thus the potassium present in the plant matter seems be recycled quickly, returning to the soil in a form readily available to the plant. Since there was a positive effect of the nitrogen doses on dry matter production, the effect observed afterwards on the soil was related to the higher potassium recycling for the higher nitrogen doses. This effect may have occurred with the lowest soil C:N ratio. The plant residue not consumed by the animals presents uniform distribution in the pasture, and depending on the management and chemical composition, it contributes greatly to nutrient cycling (Monteiro \& Werner, 1989). 


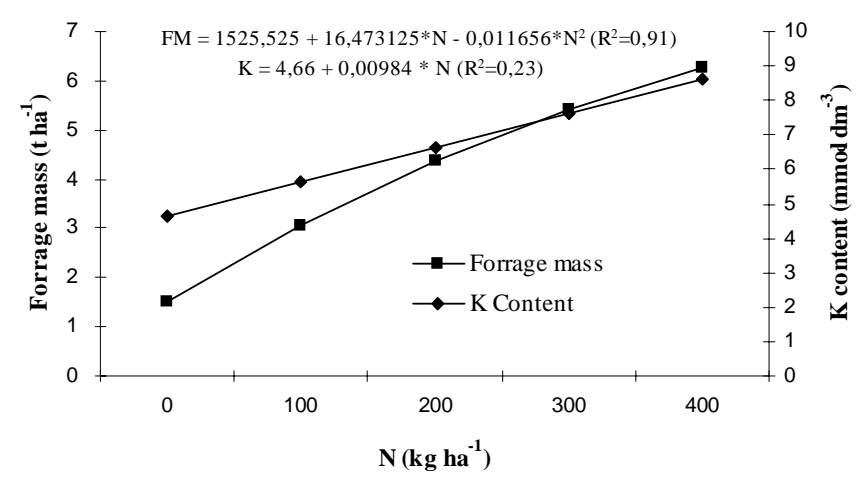

Figure 2 - Effects of nitrogen doses on potassium content in the 0-5 cm layer and on forage mass (FM).

Table 1 - Potassium content in soil cropped with marandu-grass under nitrogenated fertilization, both in presence and absence of lime

\begin{tabular}{lcccccc}
\hline & \multicolumn{5}{c}{ Doses of nitrogen $(\mathrm{kg} / \mathrm{ha})$} \\
\cline { 2 - 6 } & 0 & 100 & 200 & 300 & 400 & Mean \\
\hline & Lime K $\left(\mathrm{mmol}_{\mathrm{c}} / \mathrm{dm}^{3}\right)$ & in the 0 & $5 \mathrm{~cm}$ layer \\
Presence & 4.65 & 6.00 & 4.90 & 10.00 & 8.03 & $6.71 \mathrm{a}$ \\
Absence & 4.08 & 6.10 & 6.90 & 8.08 & 7.55 & $6.54 \mathrm{a}$ \\
Mean CV (\%) & 4.36 & 6.05 & 5.90 & 9.03 & 7.78 & 24.97 \\
\hline & $\mathrm{K}\left(\mathrm{mmol}_{\mathrm{c}} / \mathrm{dm}^{3}\right)$ & in the & 5 a 10 & $\mathrm{~cm}$ layer \\
Presence & 3.83 & 4.90 & 3.13 & 4.35 & 3.95 & $4.03 \mathrm{a}$ \\
Absence & 4.90 & 3.15 & 2.90 & 3.85 & 3.48 & $3.65 \mathrm{a}$ \\
Mean CV (\%) & 4.36 & 4.02 & 3.01 & 4.10 & 3.71 & 29.82 \\
\hline
\end{tabular}

$\mathrm{K}\left(\mathrm{mmol}_{\mathrm{c}} / \mathrm{dm}^{3}\right)$ in the 10 a $20 \mathrm{~cm}$ layer

$\begin{array}{lllllll}\text { Presence } & 2.77 & 2.11 & 2.57 & 2.22 & 2.57 & 2.43 \mathrm{a}\end{array}$

$\begin{array}{lllllll}\text { Absence } & 3.42 & 2.27 & 1.57 & 1.40 & 1.72 & 2.08 \mathrm{a}\end{array}$

\begin{tabular}{lllllll} 
Mean CV (\%) & 3.10 & 2.19 & 2.07 & 1.81 & 2.15 & 36.35 \\
\hline
\end{tabular}

Similar small letters do not differ significantly $(\mathrm{P}>0.05)$ by Tukey test. $\mathrm{CV}=$ coefficient of variation (\%)

In this experiment, the linear increase of the potassium content in the soil with the nitrogenated fertilization diverges from that reported Coutinho et al (1999), who observed an accentuated reduction in the potassium content in the soil after the $12^{\text {th }}$ cut of irrigated Tifton grass, and an increase in production with the nitrogenated fertilization. The effect of nitrogenated fertilization on raising the potassium content in the surface layer is conditioned to the presence of this mineral in the soil and to its replacement in cases of successive cuts and extractions of the produced mass. Primavesi et al. (1999) observed that doses of nitrogen reduce the extraction of potassium by oat, even when $60 \mathrm{~kg} / \mathrm{h}$ a of potassium by the straw returns to the soil. The critical level of potassium in the soil mentioned by Coutinho et al. (2004), based on the response of three forages of the
Cynodon species to the soil potassium content, was $1.4 \mathrm{mmol}_{\mathrm{c}} / \mathrm{dm}^{3}$. In the present experiment, the soil potassium content was $1.8 \mathrm{mmol}_{\mathrm{C}} / \mathrm{dm}^{3}$, and then $33 \mathrm{~kg} /$ ha were applied, which certainly contributed to the positive linear effect of nitrogen on the potassium content in the soil.

Ferrari Neto et al. (1994) reported that e nitrogen omission significantly affected the dry matter production of Panicum maximum and Brachiaria decumbens grasses. An occasional increase in the development of the root system caused by nitrogenated fertilization could increase the potassium absorption and posterior cycling.

Great potassium extraction and posterior cycling increases the soil potassium content when higher nitrogen doses are used was confirmed by the effect of nitrogen on the potassium concentration in the diagnosed leaves. There was a positive linear effect of the nitrogen on the potassium content in the leaf blade in all the evaluated months (Table 2). According to Costa et al. (2008), potassium extraction by Brachiaria brizantha cv. Xaraés increased with the nitrogen doses, with a maximum value in the nitrogen dose equal to $100 \mathrm{mg} \mathrm{dm}^{-3}$, the highest dose used in this experiment. The effects were more distinct in winter months, as a result of higher nutrient concentration because of the lower plant growth in this period.

Potassium acts on the plant metabolism, especially on photosynthesis and carbohydrate translocation, and is also an enzymatic activator (Epstein \& Bloom, 2006). Because of its function, when the plant growth is greater, the need for potassium is also greater. Nevertheless, it is difficult to discern which fraction of the absorbed nutrient could come from the plant physiological need or from the factors that facilitate its absorption. Since it is absorbed mainly by diffusion and, in small proportion, by mass flow, a probable increase in the root system volume (Ferrari Neto et al., 1994), leaf area (Alexandrino et al., 2004) and forage mass, that increases plant transpiration, may have favored potassium absorption, increasing its concentration following the increase in the nitrogen doses. Furthermore, the low capability of the gramineae to exchange cations makes them more efficient at removing monovalent cations $\left(\mathrm{K}^{+}\right)$, since soils absorb more strongly cations with higher valence $\left(\mathrm{Al}^{+3}>\mathrm{Ca}^{+2}>\mathrm{Mg}^{+2}>\mathrm{K}^{+}\right)$ (Marschner, 1995).

There are divergences in the literature regarding the effect of nitrogen on the potassium concentration leaf blade. Adams (1973) reported a reduction in the potassium concentrations in forage with the increase in production caused by nitrogenated fertilization. The joint analysis 
Table 2 - Regression equations representing the effect of nitrogen on the potassium concentration in the leaf blade in five periods of the year

\begin{tabular}{llcc}
\hline & \multicolumn{1}{c}{ Regression equation } & $\mathrm{R}^{2}$ & $\operatorname{Pr}>\mathrm{F}$ \\
\hline December 2004 & $\mathrm{Y}=21.675+0.01432 \mathrm{~N}$ & 0.21 & 0.0026 \\
January 2005 & $\mathrm{Y}=19.8775+0.01634 \mathrm{~N}$ & 0.23 & 0.0017 \\
February 2005 & $\mathrm{Y}=19.175+0.00812 \mathrm{~N}$ & 0.12 & 0.0283 \\
June 2005 & $\mathrm{Y}=15.6075+0.02152 \mathrm{~N}$ & 0.66 & 0.0001 \\
August 2005 & $\mathrm{Y}=23.7275+0.02779 \mathrm{~N}$ & 0.65 & 0.0001 \\
\hline
\end{tabular}

confirmed that nitrogen addition may increase the potassium concentration in the plant, provided the element is available in the soil, and reduce this concentration when the nutrient content in the soil is low, since a dilution in the concentration of nutrients occurs with plant development.

After liming, the plant presented higher concentrations of calcium and magnesium, the potassium content was lower, and vice-versa, as a result of the probable effect of competitive inhibition between potassium and magnesium in response to the liming (Table 3). According to Mengel \& Kirkby (2001), the competition between calcium, magnesium and potassium for the same connection sites in the charger is improbable, because of differences in the cation size and structure; this is probably due to competition for anionic equivalents in the cell, in an attempt by the plant to maintain the system electric neutrality.

The higher efficiency of the plants when monovalent cations are removed results in higher concentrations of potassium and lower concentrations of calcium and magnesium in the leaf blade, even with application of calcium and magnesium. In December, liming caused the highest potassium concentration (25.8 versus $23.2 \mathrm{~g} / \mathrm{kg}$, \pm 3.23 ), and in June, the lowest (19 versus $20 \mathrm{~g} / \mathrm{kg}, \pm 2.13$ ). The effects observed in December were due to a greater power of absorption in the rainy season and the quick solubility of potassium chloride soon after its application in November. In the subsequent months, the absence of any effect of the liming on the potassium content in the plant was related to the longest term in which potassium chloride was applied and to the absence of residual effect for significant interaction. In July, the potassium content in the soil was lower than in December, due to the absorption of the nutrient by the plant. Since the amount of calcium (364 kg/ha) applied by the lime was much higher than the amount of potassium (33 kg/ha), provided by the potassium chloride, it is probable that the effect of the amount of nutrients prevailed over the effect of the lower calcium retention in the colloidal complex because of its monovalence. So, in June, a lower potassium concentration was observed
Table 3 - Coefficients of correlation between concentrations of potassium and calcium in the leaf blade of marandugrass in five periods of the year

\begin{tabular}{lccccc}
\hline Item & \multicolumn{2}{c}{$\mathrm{K}$ and Ca } & & \multicolumn{2}{c}{$\mathrm{K}$ and $\mathrm{Mg}$} \\
\cline { 2 - 3 } \cline { 5 - 6 } & $\mathrm{R}$ & $\mathrm{p}$ & & $\mathrm{R}$ & $\mathrm{p}$ \\
\hline December 2004 & - & 0.443 & & - & 0.151 \\
January 2005 & -0.34 & 0.03 & & - & 0.769 \\
February 2005 & -0.44 & 0.004 & & -0.35 & 0.024 \\
June 2005 & -0.69 & 0.0001 & & -0.58 & 0.0001 \\
August 2005 & -0.75 & 0.0001 & & -0.47 & 0.002 \\
\hline
\end{tabular}

$\mathrm{R}=$ correlation coefficient between variables.

$\mathrm{p}=$ probability of significance for testing the hypothesis that the true correlation of the population in question is equal to zero.

with the lime application, the same period in which the concentration of calcium was greater when lime was applied.

There was a seasonal effect on the potassium content, which was higher in August (Table 4). Beringer \& Trolldenier (1978) verified that supplying potassium leads to a thickening in the epidermis cell wall and increased cell lignification. Since in tropical grasses the lignin concentration increases as the plant matures, both in the culm and leaves (Morrison, 1980), and since the leaf analyzed in August came after a greater rest period and therefore from more mature plants, the potassium concentration was higher in the leaf blade sampled in this period. The sampling period is extremely important in the evaluation of the plant nutritional condition. Thus, this seasonal effect may be related to the low temperature and water stress in August, resulting in an increase of nutrient concentration in plants with limited growth (Jarrel \& Beverly, 1981).

The potassium concentration in forage plant tissue varies greatly with the nutrient availability in the soil. Monteiro et al. (1995) observed that the omission of potassium resulted in a lower potassium content in the canopy manadu-grass dry matter than the application of potassium (4.3 versus $28 \mathrm{~g} / \mathrm{kg}$ ). Mattos \& Monteiro (1998) obtained a critical level equal to $22 \mathrm{~g} / \mathrm{kg}$ dry matter for marandu-grass. In this experiment, the mean values found for potassium, from 20 to $29 \mathrm{~g} / \mathrm{kg}$, were within the range cited by Werner et al. (1996) as adequate for the species (12 to $30 \mathrm{~g} / \mathrm{kg}$ ), and within the critical level detected by Mattos \& Monteiro (1998), therefore the plant was well-nourished in potassium.

The forage residue contributes to increase the potassium content in the soil surface layer. Nevertheless, the increase in the production mass and potassium concentration in the plant caused by the nitrogenated fertilization corroborated the importance of supplying this mineral in order to intensify the production systems in marandu-grass pastures. 
Table 4 - Potassium concentration in leaf blade of marandugrass cultivated with nitrogenated liming in different periods of the year

\begin{tabular}{lcccccc}
\hline \multirow{2}{*}{ Nitrogen $(\mathrm{kg} / \mathrm{ha})$} & \multicolumn{5}{c}{ Potassium $(\mathrm{g} / \mathrm{kg})$} \\
\cline { 2 - 7 } & December & January & February & June & August & Mean \\
\hline 0 & 22.06 & 18.83 & 19.08 & 15.17 & 23.03 & 19.63 \\
100 & 23.28 & 23.41 & 20.27 & 18.75 & 26.75 & 22.63 \\
200 & 24.33 & 22.86 & 20.66 & 19.43 & 29.75 & 23.27 \\
300 & 24.35 & 23.85 & 21.37 & 21.08 & 33.21 & 24.77 \\
400 & 28.69 & 26.78 & 22.60 & 25.11 & 33.69 & 27.37 \\
Mean & $24.53 \mathrm{~b}$ & $23.14 \mathrm{c}$ & $20.80 \mathrm{~d}$ & $19.91 \mathrm{e}$ & $29.28 \mathrm{a}$ & $\mathrm{CV}=14.22$
\end{tabular}

Similar lower case letters do not differ significantly $(\mathrm{P}>0.05)$ by the Tukey test. $\mathrm{CV}=$ coefficient of variation $(\%)$

\section{Conclusions}

Nitrogenated fertilization increased the potassium concentration in marandu-grass plants and the potassium content in the soil surface layer. There was an effect of competitive inhibition between potassium and calcium absorption, and between potassium and magnesium by the plant. Although a significant fraction returned to the soil surface layer through the forage residue, with the increase in dry matter production and potassium concentration in the plant by nitrogenated fertilization, it is important to consider the potassium supply to the plant.

\section{Literature Cited}

ADAMS, S.N. The response of pastures in Northern Ireland to N, $\mathrm{P}$ and $\mathrm{K}$ fertilizers and to animal slurries: II. Effects on mineral composition. Journal Agricultural Science, v.81, p.411417, 1973.

ALEXANDRINO, E.; NASCIMENTO JR., D.; MOSQUIM, P.R. et al. Características morfogênicas e estruturais na rebrotação da Brachiaria brizantha cv. Marandu submetida a três doses de nitrogênio. Revista Brasileira de Zootecnia, v.33, n.6, p.1372-1379, 2004.

ALVIM, M.J.; BOTREL, M.A.; VERNEQUE, R.S. et al. Aplicação de nitrogênio em acessos de Brachiaria. 1. Efeito sobre a produção de matéria seca. Pasturas Tropicales, v.12, p.2-6, 1990.

BARCELLOS, A.O. Sistemas intensivos e semi-intensivos de produção: pecuária bovina de corte nos Cerrados. In: SIMPÓSIO SOBRE O CERRADO, 8.; INTERNATIIONAL SYMPOSIUM ON TROPICAL SAVANNA 1., Brasília, 1996. Proceedings/ Anais... Planaltina: EMBRAPA CPAC, 1996. p.130-136.

BERINGER, H.; TROLLDENIER, G. Influence of $\mathrm{K}$ nutrition on the response to environmental stress. In: CONGRESS OF THE INTERNATIONAL POTASH INSTITUTE, 11., 1978, Bern. Proceedings... Bern: International Potash Institute, 1978. p.189-222.

CENTRO INTERNACIONAL DE AGRICULTURA TROPICAL CIAT. Programa de pastos tropicales. Cali: 1980. 138p. (Informe Técnico).

COSTA, K.A.P.; ARAÚJO, J.L.; FAQUIN, W. et al. Extração de macronutrientes pela fitomassa do capim-xaraés "xaraés" em função de doses de nitrogênio e potássio. Ciência Rural, v.38, n.4, 2008.
COUTINHO, E.L.M.; CONSOLINI, F.; SCATOLIN, M. Adubação nitrogenada e potássica em pastagem irrigada de Tifton 68 . Efeitos no solo, na planta e na produção de matéria seca. In: CONGRESSO LATINO AMERICANO DE LA CIENCIA DEL SOLO, 14., 1999, Pucon. Anais... Pucon: Solo-Suelo (1999). (CD-ROM).

COUTINHO, E.L.M.; SILVA, A.R.; MONTEIRO, F.A. Adubação potássica em forrageiras. In: FERTILIDADE DO SOLO PARA PASTAGENS PRODUTIVAS, 2004, Piracicaba. Anais... Piracicaba: Fundação de Estudos Agrários Luiz de Queiroz, 2004. p.480.

EMPRESA BRASILEIRA DE PESQUISA E AGROPECUÁRIA EMBRAPA. Sistema brasileiro de classificação de solos. Brasília: Embrapa-SPI, 1999. 412p.

EPSTEIN, E.; BLOOM, A.J. Nutrição mineral das plantas: princípios e perspectivas. Londrina: Editora Planta, 2006. 403p.

FERRARI NETO, J.; FAQUIN, V.; VALE, F.R. Limitações nutricionais do colonião (Panicum maximum Jacq.) e da braquiária (Brachiaria decumbens Stapf.) em amostras de um Latossolo do noroeste do Paraná: I. Produção de matéria seca e perfilhamento. Revista Brasileira de Zootecnia, v.23, p.538-551, 1994.

JARREL, W.M; BEVERLY, R.B. The dilution effect in plant nutrition studies. Advances in Agronomy, v.34, n.1, p.197-224, 1981.

KÖPPEN, W., Climatologia. Buenos Aires: Gráfica Panamericana, 1948. 478p.

MARSCHNER, H. Mineral nutrition of higher plants. New York: Academic Press, 1995. 874p.

MATTOS, W.T.; MONTEIRO F.A. Respostas de Brachiaria brizantha a doses de potássio. Scientia Agricola, v.55, n.3, 1998.

MENGEL, K.; KIRKBY, E.A. Principles of plant nutrition. Dordrecht: Kluwer Academic Publishers, 2001. 849p.

MONTEIRO, F.A.; RAMOS, A.K.B.; CARVALHO, D.D. et al. Cultivo de Brachiaria brizantha (Stapf.) cv. Marandu em solução nutritiva com omissão de macronutrientes. Scientia Agricola, v.52, n.1, p.135-41, 1995.

MONTEIRO, F.A.; WERNER, J.C. Ciclagem de nutrientes minerais em pastagens. In: SIMPÓSIO SOBRE ECOSSISTEMA DE PASTAGEnS, Jaboticabal, 1989. Anais... Jaboticabal: FUNEP, 1989, p.149-192.

MORRISON, I.M. Changes in the lignin and hemicellulose concentrations of ten varieties of temperate grasses with increasing maturity. Grass Forage Science, v.35, p.287-293, 1980 .

PRIMAVESI, A.C.P.A.; PRIMAVESI O.; GODOY RODOLFO. Extração de nutrientes e eficiência nutricional de cultivares de aveia, em relação ao nitrogênio e à intensidade de corte. Scientia Agricola, v.56, n.3, p.613-620, 1999.

SANTOS JR., J.D.G; MONTEIRO, F.A.; LAVRES JR., J. Análise de crescimento do capim-marandu submetido a doses de nitrogênio. Revista Brasileira de Zootecnia, v.33, n.6, p.1985-1991, 2004 (supl.2).

SARRUGE, J.R.; HAAG, H.P. Análises químicas de plantas. Piracicaba: Escola Superior de Agricultura Luiz de Queiroz, 1974. 54p.

STATISTICAL ANALYSIS SYSTEM - SAS. User's guide Cary: 2003. (CD-ROM).

Van RAIJ, B.; QUAGgio, J.A.; CANTARella, H. Análise química do solo para fins de fertilidade. Campinas: Fundação Cargill, 1987. 107p.

WERNER, J.C.; PAULINO, V.T.; CANTARELLA, H. Forrageiras. In: Van RAIJ, B.; CANTARELLA, H.; QUAGGIO, J.A. (Eds.) Recomendações de adubação e calagem para o Estado de São Paulo. Campinas: Instituto Agronômico de Campinas, 1996. p.261-273. (Boletim Técnico, 100). 